\title{
Cassava farmers Limitations and Utilization of Agricultural Information in Delta State, Nigeria
}

\author{
Omoregbee, F. E.; Awhareno, U. S. And I.D. Ekpebu
}

\begin{abstract}
The study examined cassava farmers' limitations and utilization of agricultural information in Delta State. A multi-stage sampling technique was used to select 146 cassava farmers across the state. Data collected through structured questionnaire were analyzed using descriptive statistics and Spearman's rho correlation. Findings revealed that respondents' had access to information on available market for produce, produce price, input price, improved cassava varieties, fertilizer type and fertilizer application. It was also observed that respondents utilize this information in their farm enterprise. The study identified poor communication, wrong communication channels and inadequate fund and epileptic power supply as major constraints associated with accessing agricultural information. A test of significance between information access and utilization showed that information on pest control method, disease control method, processing equipment and packaging were significant

Key words: Agricultural Information, Cassava farmers, Delta State, Limitations Utilisation.
\end{abstract}

\section{Introduction}

Agriculture has been the main source of food and raw materials for the ever increasing population in Nigeria. It has been argued that for agriculture growth to occur in Nigeria, it will be through information dissemination on improved technologies. Ozowa (2004) noted that information and communication are essential ingredients needed for effective transfer of technology that are designed to boost agricultural production. Many valuable results have been obtained from most of the agricultural research institutes in Nigeria; however, most of these improved agricultural practices do not get to the farmers. This situation has created a wide gap between research and utilization of the research results.

The evidence from the Research-Extension-Farmer-Input-Linkage-System (REFILS) workshops organized in each of the agricultural zones of the country have accumulated a lot of technology for improving agricultural practices in the country (Fabiyi, 2001). For instance, the combined efforts of National Root Crop Cereal Research Institute (NRCRI) and International Institute of Tropical Agriculture (IITA) has developed appropriate agronomic practices for cassava production, including cultural control measures for pest and diseases of cassava, high-yielding and disease resistant varieties and fertilizer. The combined efforts of Product Development Agency (PRODA), Federal Institute of Industrial Research, Oshodi (FIIRO) and International Institute of Tropical Agriculture (IITA) has also led to the development of labour-saving technologies to remove the drudgery faced by cassava farmers and processors.

Abolaji et al. (2008) observed that the Nigerian Government has employed Science and Technology (S\&T) to develop higher-yielding and pest resistant cassava varieties. With this avalanche of information, farmers are still faced with numerous challenges in cassava production, processing and marketing. Abolaji et al (2008) asserted that the average cassava yield is very low, ranging from 7-10 tons per hectare, which is much lower than the world average of $30-40$ tons per hectare. It is against this background that this study assessed the level of utilization of agricultural information and limitations to the utilization of such information by cassava farmers in the Delta state.

The objectives of the study were to:

i. ascertain cassava farmers' access to agricultural information.

ii. assess the level of utilization of agricultural information by cassava farmers.

iii. identify factors that limit cassava farmers from utilizing agricultural information.

The hypothesis of the study is as follows:

Ho: There is no significant relationship between access to and utilization of agricultural information by cassava farmers.

\section{Methodology}

The study was carried out in Delta State. Delta State is one of the six states in the South - South geopolitical zone of Nigeria.The state has a total land area of 17,698 square kilometers and a population of 4,098,391 million people made up of different ethnic groups (Wikipedia, 2006). Administratively, the State is 
made up of 25 Local Government Areas constituted into three senatorial districts. The State is blessed with two agro-ecological zones, riverine and upland, with abundant resources backed by oil wealth. The inhabitants are mostly farmers and farming activities is their primary source of livelihood. The major arable crops grown are cassava, yam and maize. The study focused on farmers who have cassava as their main crop. A multi-stage sampling technique was adopted in selecting the respondents. A total of 146 cassava farmers were selected across the state as follows, the state was was stratified into three agro-ecological zones- Delta North, Delta central and Delta South zones. A simple random sampling of two blocks was selected in each zone to produce a to tal of six blocks. A simple random selection of three cells was undertaken in each block to give a total of 18 cells. A simple random sampling of 10 cassava farmers was selected in each cell to give a total sample of 180 cassava farmers. However, only 146 copies of returned structured interview schedule were found useful for the study.

Descriptive statistical tools such as tables, frequency counts, and percentages were used to analyse data while Spearman's rho (p) correlation was used to test the relationship between access to and utilization of agricultural information by the farmers. Respondents' access to and utilization of fifteen(15) agricultural information types were measured on a three point scale as follows: always (3), sometime (2) and never (1 point). The minimum and maximum scores on an access and utilizsation scale were 15 and 45 respectively. Nineteen (19) constraints items to accessibility of agricultural information was measured on 5-point scale of strongly agreed (5), agreed (4), undecided (3), disagreed (2) and strongly disagreed (1). The minimum and maximum scores on the f5-point scale were 19 and 95 .

\section{Results and discussion}

3.1 Cassava farmers' access to agricultural Information: Table 1 looked at respondents' access to agricultural information. Results indicated that the respondents had access to information on available market for produce (mean $=2.30$ ), produce price $(2.1)$, improved cassava varieties $(2.1)$, fertilizer type (2.1), fertilizer application (2.1). This result indicated that cassava farmers had access to six agricultural information types and suggests that they know where to get this information. Respondents' access to agricultural information can be generally described to be low because they had access to only six information types as against fifteen information types.

Table 1: Distribution of respondents by access to cassava related information

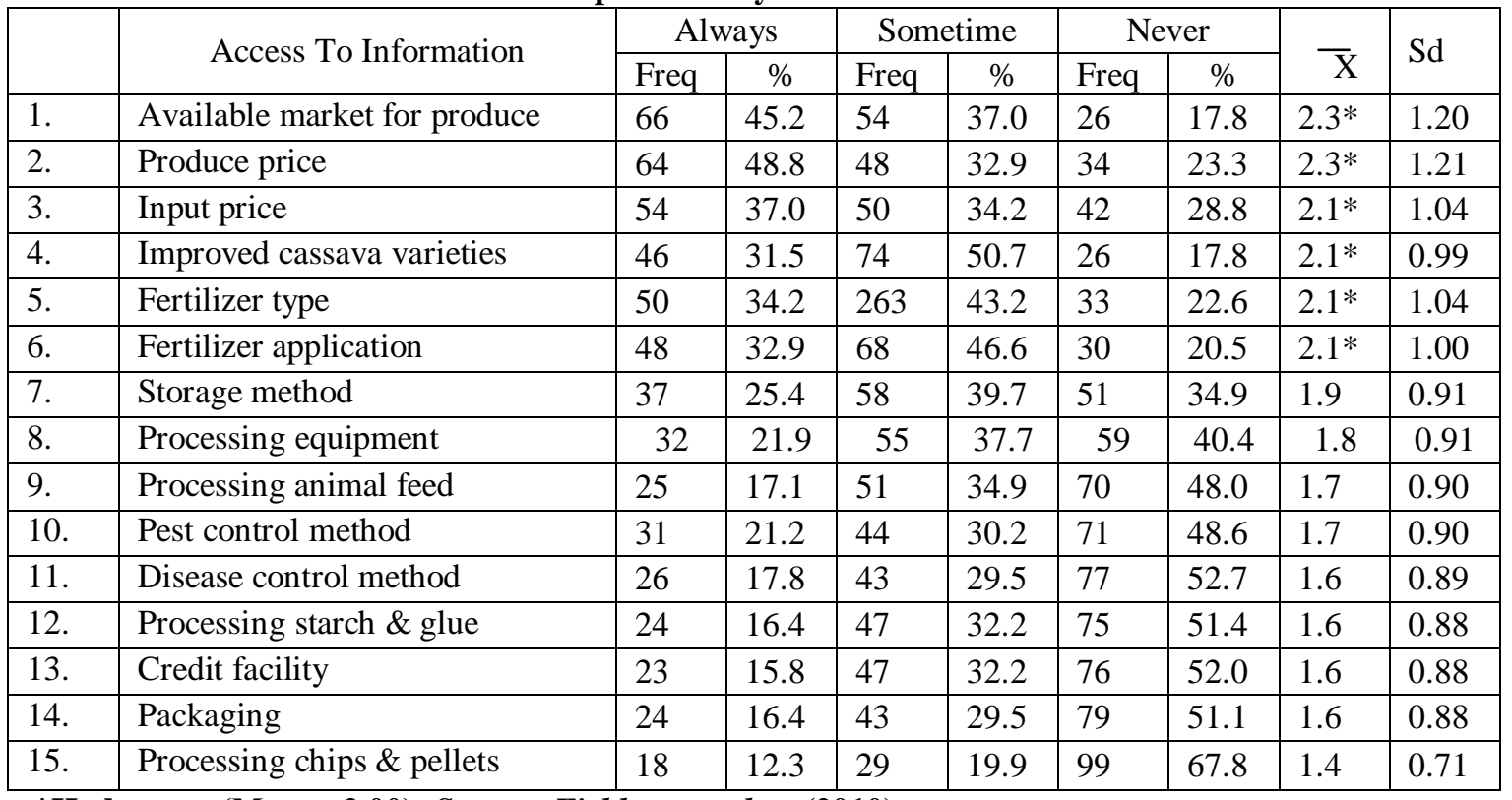

*Had access (Mean $\geq 2.00)$; Source: Field survey data (2010).

\subsection{Utilization of agricultural information}

As shown in Table 2, the agricultural information regularly utilized by the respondents produce price with a mean value of 2.2, improved cassava varieties (2.2), produce market available (2.2), input price (2.1), fertilizer type (2.1) and application (2.1).

The level of information use for other technologies was non-frequent. For example the results of the Table showed that information on Processing chips and pellets, Credit facility, packaging, processing animal feed and Processing starch and glue were not regularly used. The result shows that respondents mainly used information 
on improve cassava varieties, fertilizer type, fertilizer application, available market for produce, input price and produce price. Interestingly these were the same information respondents had access to. By implication, this means, if farmers have access to other information they will also use same

Table 2: Distribution of respondents by use of cassava related information

\begin{tabular}{|c|c|c|c|c|c|c|c|c|c|}
\hline & \multirow{2}{*}{ Information use } & \multicolumn{2}{|c|}{ Always } & \multicolumn{2}{|c|}{ Sometime } & \multicolumn{2}{|c|}{ Never } & \multirow[b]{2}{*}{$\mathbf{X}$} & \multirow[b]{2}{*}{ Sd } \\
\hline & & Freq & $\%$ & Freq & $\%$ & Freq & $\%$ & & \\
\hline 1. & Produce price & 67 & 45.9 & 46 & 31.5 & 33 & 22.6 & $2.2 *$ & 1.31 \\
\hline 2. & Improved cassava varieties & 57 & 39.0 & 66 & 45.2 & 23 & 15.8 & $2.2 *$ & 1.22 \\
\hline 3. & Available market for produce & 60 & 41.7 & 55 & 37.7 & 31 & 21.2 & $2.2 *$ & 1.21 \\
\hline 4. & Input price & 56 & 38.4 & 44 & 30.1 & 46 & 31.5 & $2.1 *$ & 0.97 \\
\hline 5. & Fertilizer type & 45 & 30.8 & 69 & 47.3 & 32 & 21.9 & $2.1^{*}$ & 0.96 \\
\hline 6. & Fertilizer application & 45 & 30.8 & 67 & 45.9 & 34 & 23.3 & $2.1^{*}$ & 0.71 \\
\hline 7. & Processing equipment & 37 & 25.3 & 52 & 35.6 & 57 & 39.1 & 1.9 & 0.70 \\
\hline 8. & Storage method & 42 & 28.8 & 46 & 31.5 & 58 & 39.7 & 1.9 & 0.70 \\
\hline 9. & Pest control method & 34 & 23.3 & 45 & 30.8 & 67 & 45.9 & 1.8 & 0.97 \\
\hline 10. & Disease control method & 28 & 19.2 & 43 & 29.5 & 75 & 51.3 & 1.7 & 0.97 \\
\hline 11. & Processing starch and glue & 23 & 15.8 & 44 & 30.1 & 79 & 54.1 & 1.6 & 0.70 \\
\hline 12. & Processing animal feed & 25 & 17.1 & 43 & 29.5 & 78 & 53.4 & 1.6 & 1.30 \\
\hline 13. & Packaging & 28 & 19.2 & 34 & 23.3 & 84 & 57.5 & 1.6 & 1.21 \\
\hline 14. & Credit facility & 21 & 14.4 & 48 & 32.9 & 77 & 52.7 & 1.6 & 1.30 \\
\hline 15. & Processing chips and pellets & 18 & 12.3 & 24 & 16.4 & 104 & 71.3 & 1.4 & 0.72 \\
\hline
\end{tabular}

*Regularly used (mean > 2.00); Source: Field survey data (2010).

\subsection{Limitations associated with accessing agricultural information}

The factors that acted as limitation to respondents' access to agricultural information are as shown in Table 3. The serious limitations were poor communication $(M=3.40)$, inappropriate communication channels $(M=3.23)$, inadequate fund to search for cassava related information $(M=3.06)$ and irregular electricity supply to power electrical appliance $(\mathrm{M}=3.05)$. The study identified poor communication, inappropriate communication channel, and inadequate power supply as serious constraints to the accessing of agricultural information.

FAO (2007) noted that for any agricultural information to be useful it must be effectively communicated to farmers. When inappropriate communication channels are used and at a wrong time, farmers will not be able to access the information. William (1989) and Omokhudu (1999) identified poor communication and wrong communication channels and facilities as one of the primary constraints to accessing information and agricultural development in Nigeria. The implication of this is that results on improve farming techniques in research institutes are unable to reach the target farmers.

Empirical evidence has shown that the cost of accessing agricultural information is a major limitation (Chris, 2001). Agricultural information may be free but accessing such information may not be free. This indicates that resource poor farmers may not have the financial resources to access agricultural information even when they are given freely. Furthermore, the absence of electricity constituted a remarkable hindrance to agricultural information access. Without electricity, radio and television will not be useful to a resource poor farmer who may not be able to afford a generator.

Table 3: Limitations Associated with accessing agricultural information

\begin{tabular}{|l|c|c|}
\hline \multicolumn{1}{|c|}{ Constraints } & Mean & SD \\
\hline Poor communication & $3.40^{*}$ & 1.3 \\
\hline Inappropriate Communication channel & $3.23^{*}$ & 1.3 \\
\hline Lack or funds to search for information & $3.06^{*}$ & 1.4 \\
\hline Lack or electricity to power my radio/TV & $3.05^{*}$ & 1.5 \\
\hline Do not know where to get information & 2.75 & 1.4 \\
\hline Radio station have no Agric program & 2.73 & 1.3 \\
\hline Agricultural information is too complex & 2.63 & 1.3 \\
\hline My farm plots is too small & 2.62 & 1.4 \\
\hline T.V station have no Agricultural program & 2.54 & 1.2 \\
\hline No extension agent in my area & 2.54 & 1.4 \\
\hline Radio/TV broadest only in English & 2.39 & 1.3 \\
\hline Extension agent speak only English & 2.31 & 1.2 \\
\hline
\end{tabular}


Cassava Farmers LIMITATIONS And Utilization Of Agricultural Information In Delta State,

\begin{tabular}{|l|c|c|}
\hline Do not belong to any social group & 2.30 & 1.2 \\
\hline I cannot write & 2.03 & 1.3 \\
\hline I cannot read & 1.99 & 1.2 \\
\hline I have no television & 1.99 & 1.1 \\
\hline I have no radio & 1.96 & 1.1 \\
\hline I do not understand English & 1.86 & 1.0 \\
\hline My religious belief & 1.82 & 0.9 \\
\hline My culture forbid improved varieties & 1.68 & 0.7 \\
\hline
\end{tabular}

* Serious Limitation (Mean $\geq 3.00)$, Source: Field survey data (2010)

\subsection{Correlation results between farmers' access to and utilization of agricultural information}

The result of the correlation analysis between farmers' access to and utilization of agricultural information is shown in Table 4. The result shows that only four out of the fifteen explanatory variables in the model were positive and significant at $5 \%$ level. These were pest control method $(\mathrm{r}=0.203)$, disease control method $(r=0.214)$, packaging $(r=0.186)$ and processing equipment $(r=0.161)$. The positive signs imply that the more access respondents have to this information the more likely they will utilize that information.

Table 4: Correlation between farmers access to and utilization of agricultural information

\begin{tabular}{|l|c|c|}
\hline \multicolumn{1}{|c|}{ Variables } & Correlation coefficient $(\mathbf{r})$ & Significant \\
\hline Improved cassava varieties & -0.048 & NS \\
\hline Fertilizer type & 0.142 & NS \\
\hline Fertilizer application & 0.055 & NS \\
\hline Pest control method & $0.203^{*}$ & S \\
\hline Disease control method & $0.214^{*}$ & S \\
\hline Processing chips and pellets & -0.016 & NS \\
\hline Processing starch and glue & 0.059 & NS \\
\hline Processing animal feed & 0.091 & NS \\
\hline Processing equipment & $0.161^{*}$ & S \\
\hline Storage method & 0.120 & NS \\
\hline Packaging & $0.189^{*}$ & NS \\
\hline Available market for produce & 0.61 & NS \\
\hline Input price & 0.133 & NS \\
\hline Produce price & 0.140 & NS \\
\hline Credit facility & 0.035 & \\
\hline
\end{tabular}

Significant at 5\% (Critical $r=0.155)$

\section{Conclusion}

The findings from the study show that respondents had access to six agricultural information types namely available market for produce $(45.2 \%)$, produce price $(48.8 \%)$. input price $(37.0 \%)$, improved cassava varieties $(50.7 \%)$, fertilizer type ( $43.2 \%$ and fertilizer application $(46.6 \%)$. The result revealed that respondents utilise the same six information type that they have access to. The study identified four major limitations to accessing agricultural information by cassava farmers. These are poor communication, inappropriate communication channels, inadequate fund to search for information and epileptic electricity supply.

The test of relationship between access to and utilization of agricultural information showed only pest control method, disease control method, processing equipment and packaging were statistically significant.

Based on the findings of the study, the following suggestions were made as follows:

1. Cassava farmers had access to and use six out of the fifteen agricultural information types. There is need to enhance farmers' access to the nine remaining agricultural information types as their access the information will naturally lead to their being utilsed.

2. Poor electricity supply to rural areas is a major drawback to access to and use of agricultural information by farmers. As a remedial measure, farmers should be encouraged to buy small transistor radio sets that depend on dry cell batteries, in addition to increasing the supply of rural extension and advisory services to them.

\section{References}

[1] Abolaji D.D, Siyanbola, W. O, Oladele, O. A. and Isiaka A. O. (2007): Capacity innovations in cassava production, harvesting and processing in Nigeria. http:llwww.nigeriainvestment.com /story.php. assess April, 2009.

[2] Chris, G., (2001): Agricultural knowledge and information system in Hagaz, Eritres. International and Rural Development Department. The University of Reading, United Kingdom http:llwww.fao.org/sd/2001/kn1001a- en.htm. assessed $12^{\text {th }}$ December, 2008. 
[3] Fabiyi, E.F. (2001): Source of information on new farm practices; A case study of farmers in Dass Local Government Area, Bauchi State, Nigeria. Proceedings of the seventh annual national conference of the Agricultural Exten sion Society of Nigeria $19^{\text {th }}-$ $22^{\text {nd }}$ August, 2001 144-146.

[4] Food and Agricultural Organisation (2007): Communication for development. http:llwww.fao.org/nrlcom.en.htm

[5] Food Agricultural Organisation (2007): Approaches to linking Producers to market, A review of experiences to date. FAO of the United Nations, Rome.

[6] Omokhudu, C.O. (1999); A study of various agencies communicating agricultural information among selected farmers in Owan East Local Government Area of Edo State. Proceedings of the fifth annual national conference of the Agricultural Society of Nigeria. $12^{\text {th }}-$ $14^{\text {th }}$ April, $99-105$.

[7] Ozowa, V.N. (2004): Information Needs of Small Scale Farmers in Africa. The Nigeria Example. Quarterly Bulletin of the International Association of Agricultural Information Specialist, IAALD/CABI, vol. 40 No 1 PP $22-30$

[8] Wikipedia, (2006): Demographics of Nigeria. http:llen.wikipedia.org/ wiki/demographics-of-nigeria. William, C.E.C.(1989): women in Nigeria agriculture, A Discussant paper presented at the National Symposium on the Nigeria Question December 1113. 